\title{
Management Function on Leadership of Education at Community Learning Center
}

\author{
Moh. Muzaqi \\ Universitas Negeri Surabaya \\ Surabaya, Indonesia \\ moh.muzaqi@mhs.unesa.ac.id
}

\begin{abstract}
The purposes of this research is to describe the implementation of management function on: (1) leadership of education of the head in managing CLC, (2) the tasks and the function of CLC, (3) the implementation of empowering program at CLC. The research results showed that: first, the implementation of management function of the heads leadership on education in managing CLC, were: (1) proactively effort to seek institutional status and designing programs, (2) the heads competence and role to manage the program, (3) task and function of the head, and (4) model of bureaucracy of the head in managing CLC. second, the management function in implementing its tasks associated with: (1) stage of planning application and evaluating the learning, (2) supporting factors of CLC tasks, and (3) the barrier joint task implementation. Third, the management function of CLC empowering to: (1) the program is oriented on the learning of community based needs, (2) institutional strengthening program of CLC, (3) development program of institution, and (4) public participation program aimed at empowering people.
\end{abstract}

Keywords-management, leadership education, unit of non formal education

\section{INTRODUCTION}

One form of educational unit that can organize NFE programs in the district or city is a Community Learning Center (CLC). The existence of CLC is important as an NFE unit that has the human resources potential that needs to be optimized in term of task and role.

CLC educational leadership requires to retaining ability and creativity to achieve organizational goals. Leadership competence and creativity are positively correlated with achievement and work result and leadership model. (Bambang, 2013)

Talking about the leader's responsibility to members in the process of managing educational institutions, Wahab (2014) provides insight into the application of transformational leadership in managing institutions. That is, leaders have a responsibility to encourage subordinates to change attitudes by committing themselves into mission and educational vision. Institutions Leaders invite all elements in the institution to succeed in achieving the desired vision, mission and objectives. The head of the CLC has responsibility to influence functional personnel of the learning staff and general functional personnel to commit to the vision, mission and objectives of the CLC.
Head of CLC is a learning guard who is given additional togas to lead, plan, organize, implement and control the implementation of the program. Leadership competencies are very necessary in the CLC management. Therefore, the head must be able to implement the agency's management functions. Leadership competence is an essential requirement for management effectiveness, carrying out his/her roles, duties, functions, and responsibilities.

The leader of the institution must have sufficient knowledge and skills related to his/her duties and functions. Leaders of competent educational institutions should be able to design programs that fit the needs of learning and should be able to organize learning programs in accordance with the duties and functions. Leaders must be able to create change and mobilize the potential of human resources owned by the institution. Burns (2003) said the ability of leaders in empowering existing resources as follow: he/she must be able to impress their subordinates, must be able to realize changes in society, must be able to keep the followers, and must be able to move their personnel' ability and potential.

An effective leadership model is linked to the implementation of management functions in educational leadership. Through the leadership of education applied by the head of the CLC, it is expected to create a stagnant working atmosphere and the provision of effective NFE program services. Effective educational leadership can be a determining success factor for CLC heads to implement their duties and functions as leaders. The success of the management of educational institutions is one of them. It is influenced by the ability of the leadership, leadership to coordinate and cooperation with related institutions. They involve the existing human resources, empowering the administrative staff, optimizing the involvement of the community and partner institutions appropriately in decision making, the existence of institutions in the program implementation.

The success of leadership is also influenced by the role and performance of the leadership in managing institution. Competencies of the head of education are supported by the behavior manifestation in carrying out management functions in managers, creating a harmonious working atmosphere, and able to empower human resources in the institution. Leaders capability to apply management functions in the educational leadership 
process under the CLC is characterized by the ability to develop program planning, establishing and implementing organization, program, and conduct monitoring and evaluation. Here are the problems stated as the research question in this research:

1. How is the mangement function implementation in leadership?

2. How does the management function implementation perform their duties and functions?

3. How is the management function implementation in CLC empowerment program?

\section{Management Functions}

Management can be defined as the process of planning, organizing, staffing, leadership and controlling the resource use in achieving organizational goals effectively and efficiently. Management is the process and stage undertaken by members of the organization in order to achieve the expected objectives by working together and other organizational resources (Caldwnll, 2014). The definition of management by Follet (1998) is the art to be used to complete a job through other people / parties. According to Griffin (2000), management is a process and a stage that starts from planning, organizing, coordinating, and controlling human resources and other resources. Lee (2009) defines management as the art of planning, organizing as well as implementing directives and supervision of human resources to achieve organizational goals that have been established. Beatty (2000), adds the definition of management as planning, implementation activities and stages of implementing organizational control activities.

Management implementation is the organization led by a manager to manage the existing human resources within the organization. Stages and process implementation of management is part of management functions. Robbins (2012) and Handoko (2009) state that the management function consists of: planning, organizing, personnel preparation, direction, and supervision. Terry (2005) suggest that the implementation of management functions contains planning, organizing, implementation, and control.

Management functions in the implementation of the management of educational institutions will always be a basic element and will always exist and inherent in it The process and stages of management will be a reference for managers / leaders to implement the process of education activities so that the goal of education can be achieved effectively and efficiently Implementation of education management functions and educational leadership in it will be related to each other

\section{Educational Leadership}

Leadership can also be interpreted as a process. In addition the definition can also be equated with a production process in a production management system. Because it is a production process then the elements of leadership consists of input, process and results / output of the leadership (Wirawan, 2013). The core of leadership is the leaders and members. Leaders are responsible for the process of organizational development and human resource development. Leadership takes a while the length of time associated with leadership situations and the quality of leaders and the followers.

Sarros \& Santora (2006) define leadership as a leader's behavior undertaken to influence the activities of subordinates as group members in order to achieve the designed objectives in which the outcomes can benefit the members of the organization. Robbin (2012) defines leadership as the ability to influence groups to achieve goals. Leadership emphasizes the managerial ability of leaders in making subordinates to achieve common goals.

According to French and Raven (2002) leadership has the authority to; a) reward power, reward subordinates who follow directions, b) coercing power, giving punishment to subordinates who do not follow directions, c) legitimate power, using influence, d) referring power to organize, and d) expert power to affect the behavior of subordinates. Hughes and Corphy (2002) stated that leadership is a science and an art. As a science, leadership has objects, methods, and theories. As an art, leadership can be applied to lead in social systems, and influences on logical reasoning, inspiration and desires. Leadership process can be done well when the leader is able to create the vision and mission and can influence the followers to realize the vision and mission (Wirawan, 2013).

Education leadership competence is one of the competencies that must be owned by the educational institution. Educational leadership model that can be applied is the leadership of learning. It is usually applied by the principal in the school or education institution. In carrying out the leadership of learning, principals focus their leadership to produce better learning outcomes. (Ackfeldt 2005) states that educational leadership is defined as the science of leadership applied in the field of education. Science is applied to lead education activities in order to achieve the goal of education through learning process. Process of organizing educational leadership must be based on the legislation provisions and applicable national standards of education (Wirawan; 2013)

\section{METHOD}

The informants in this research consisting of 6 respondents, pervading 1 head of the education office, 1 SKB head and 4 employees.

The research method is qualitative approach and case study research type. The objective was to explain the management function implementation in educational leadership of Learning Activity Workshop (CLC) as NFE unit. The technique employed to collect data in accordance with research questions was through in-depth interviews, participant observation, and documentation.

\section{DISCUSSION}

Education leadership process in CLC is a management functions implementation. The process starts from planning, organizing, implementing, monitoring and evaluation. Management functional implementation in education leadership of CLC is frequently followed by the change of institutional status of CLC through a process and stages that must be done by the leadership and all the 
existing manpower. Stages and processes of educational leadership refer to the theory and principles of management implemented through stages and process namely 1) planning, 2) organizing, 3) implementation, and 4) monitoring and evaluation.

Stages and processes through the management functions implementation are initiated from steps to obtain institutional status and program setting, execution of duties and functions of CLC, and implementation empowerment program in CLC. All is done by the leadership joint to the existing CLC staffs to starts and formulates the planning, organizes the involved resources, the stage of implementation activities in accordance with the planning and objectives, as well as supervision and assessment for quality control activities.

Implementation of Management Functions on the Leadership of the Head

Bush (2007) says that the core and management of education is the process of determining the goals to be achieved by educational institutions. As a leader, he or she performs coordination steps with various parties who have the authority to formulate education policy particularly those relating to NFE program policies. This is in accordance to Leslie and Lloyd (2000) who said that one of the functions of management is to plan and determine the goals to be achieved by educational organizations.

One of the main tasks of educational institution leaders is to develop organizations and to educate their members. The effort is done so that the organization can adjust the needs of learning and the community as users of education services. Sange (1998) stated that the organization must be learnt by leaders through adaptation with the evolving needs of customers and the demands of environmental change.

Leadership is a leader's behavior to influence subordinates so that the desired goals can be achieved. According to Robbin (2012) leaders must have the ability to influence group members to jointly achieve the desired goals. Leadership skills are not separated from managerial skills. Managerial ability can be defined as competence in managing the organization. In relation to the CLC management, the head of CLC must have managerial capability to organize, implement and supervise.

Head of CLC should be able to plan short-term, medium-term programs and long term. In addition, the head should also be able to empower and utilize human resources and assets that are available with their best, although the conditions are limited. In the leadership of education, the position of a leader is as an agent of change, which is expected to create innovation and continuous change in the institution.

In relation to the leadership of education in CLC, it is expected that the head must possess such things as follow: 1) personal who can be role models, 2) activator who can influence and direct the progress, 3) communicator who are able to communicate a vision and mission, 4) responsive to changing demands of community learning needs as well as government policies, and 5) decision makers and solution providers to emerge the problems. Implementation of a head leadership model is adapted to specific situations and conditions. Based on the findings of the study, the head leadership model in managing CLC such as the situational leadership type was developed by Blanchard (1992). It is the participation and supportive style. Participative style means leaders who include subordinates in the decision-making process.

Implementation of Management Functions on the Duties and Functions

The functions of the CLC as a unit of the NFE are: 1) the formation of study groups, 2) learning and mentoring, 3) curriculum development, teaching materials, and learning media, 4) learning evaluation, and 5) pilot program. This is in accordance with its function as an educational unit to carry out teaching and learning activities and pilot programs. The learning and guidance programs organized by the CLC are aimed at serving people who do not get formal education services. Based on the research findings, the tasks and functions that have been implemented and adapted to the theoretical concept of the NFE are as follows: a) the existence of funding guarantee for the implementation, b) the implementation of learning is done with the fulfillment of learning components to ensure the quality of graduates, and c) implementation the planning, implementation, and controlling.

Stages of task planning and function are as follows: a) coordinate and communicate with the Educational Official to know the determination and approval of programs to be held at CLC, b) consolidate with all employees to design the program implementation in accordance with the stipulation and approval of policy makers, c) identifying community learning needs in accordance with program design, and d) engaging discussions with partners and communities who will be program providers outside of the CLC.

The organizing phase for carrying out the duties and functions of the CLC as a NFE unit is by: a) conducting an inventory of employee's potential and competencies, b) delegating authority and duties to employees in accordance with their positions and responsibilities, c) selecting appropriate employee names to be the responsible person who will carry out the activities, and d) prepare the job description of each personnel of the committee and create a harmonious working system. Organizing is determined by the head in the form of organizational structure of the committee. Furthermore, the organizational structure is formally defined by the Decree of Head of CLC.

The role of the head in the implementation of duties and functions of the CLC is to mobilize and provide motivation to engage in the process of activities. This is in line with what Terry (2012) says that in the implementation phase, a leader moves people within the organization to use leadership means and interaction in performing their duties. Implementation requires the spirit and dedication in carrying out duties and support and commitment.

The findings of the research shows that the supervision was conducted by the head of the CLC and the official guardians through supervision and monitoring activities which was conducted in the early, mid, and end 
of activities. Supervision and monitoring aim to see the suitability of the implementation of the program with the planning, the performance of the committee with the job description being compiled, knowing the problems that arise, knowing the initial condition / preparation of the implementation, the ongoing activity process, and how the basil and the implementation of the learning activities.

\section{Implementation of Management Function in Empowerment Program}

Empowerment in the context of NFE as conveyed by Kindervetter (Widodo, 2015) is an effort to empower communities to have good bargaining days, be able to control their socio-economics, participate in community activities, and be able to perform decision-making skills in community development. Furthermore, Natayan (2002) states there are 4 (four) elements that can serve as benchmarks in community empowerment namely: 1) provide access and information easily and appropriately; 2) provide opportunities for the community to actively engage in activities; 3) provide roles and responsibilities; and 4) establish an organization that provides services to the community.

Community empowerment program through NFE program is an enabling effort to the community members with all its limitations and its existence. Powerful communities can join the community empowerment if it is able to change its potential into a power that can change the din and circumstances that can contribute to their lives. Therefore, the CLC program needs to be done through appropriate and gradual management process. Management function in empowerment program in CLC is held with reference to the concept of empowering and sustainable theory. Therefore CLC is based on: 1) program oriented to community needs, 2) strengthening institutions, 3) the emergence of community participation and participation.

The overall involvement of the community in the implementation of the program in the CLC is not an integral part. Empowerment that brings about the full participation of the community can be done through: the involvement of the community as learners, the involvement of the community when acting as the manager or responsible for activities, and involvement in the financing. Community participation is very meaningful for the sustainability of the implementation of programs implemented by CLC.

\section{CONCLUSION}

1. Implementation of the management function in the leadership of the head in managing the CLC are in the form of: a) seeking the change of CLC into NFE units, b) applying leadership type. c) applying role in planning, organizing, implementing and supervising, and) applying the appropriate leadership model

2. Implementation of management functions on the duties and functions of CLC are: a) the formation of learning groups, b) preparing the program planning tasks and functions with reference to the identification of learning needs c) organize program implementers, d) learning to teach the program, and e) monitoring and evaluating.
3. Implementation of management functions in the empowerment program were done by means of: a) community-oriented program of learning needs, b) institutional strengthening as a unit, c) institutional development for program sustainability, and d) encouraging community participation in organizing programs as managers, learners, and supporting funding.

\section{REFERENCES}

[1] Ackfeldt, AL \& Leonard, VC. 2005. A study of organizational citizenship behaviors in a retail setting. Journal of Business Research. Vol 58. 151-159

[2] Bambang HS, 2013 , KepemimpinanPendidikanPadaLembagaPendidikanNonforma l', Disertasi S3 ManajemenPendidikanUniversitasNegeri Malang

[3] Bass, Benard M. 1994. Theory Research and Managerial Applications, $3^{\text {rd }}$ ed. New York. The Free Press

[4] Bogdan, R. C. \&Biklen,K.S. 1982. Qualitative Research for Education, An Introduction to Theory and Methods. Massachusetts: Allyn and Bacon, inc.

[5] Beatty, Brenda R. 2000. The emotions of educational leadership: breaking the silence. International Journal Leadership In Education, Vol 3 No 4, p 331-357.

[6] Burn, J.M. 2003. Leadership and Management. New York. Harper and Row

[7] Bush, Tony. 2007, Educational leadership and management: theory, policy, and practice. South African Journal of Education. Volume 27(3)391-406

[8] Caldwell, B. 2014. The Principal as Leader of The Self Managing Scholl in Australia. Journal of Educational Administration, 30:6-19.

[9] Frenh, J. \& Raven, B. 2002. The Basic of Social Power, in D. Cartwright and A. Zander (eds.), Group MCC, New York

[10] Follet, Mary P, 1998. Management and Organization. McGraw-Hill, New YorkGriffith, Ricky W. 2000. Management 5th ed. Princeton, NJ. Houghton Mifflin Co

[11] Handoko, T Hnai (2009). Manajemen, edisi 22. Yogjakarta. BPFE Universitas Gajah Mada

[12] Kindervatter, Suzanne. 1998. Non Formal Education as An Empowering Process With Case Studies From Indonesia and Thailand. USA. Massachusetts

[13] Lee. Kim Lian. 2009. The Study of Mentoring and Leader Member exchange on Organization Commitment Among Auditors in Malaysia Sunway Accademic Journal: 147-172

[14] Robbins, Stephen P \& Coulter. 2012. Managemen and Organization Behavior, $11^{\text {th }}$ Edition. New Jersey: PrenticeHall Inc

[15] Sange, Peter. 1998. The leaders's new work building learning organization. New York. Doubleday

[16] Sarros, J.C. \&Santora, J.C. 2006. The TransformationalTransactional Leadership Model in Practice. Leadership \& Organizational Development. Journal, 22, 2/8, pp. 383-393

[17] Terry, George R. 2012. Guide to Management, edisi terjemah “Prinsip-Prinsip Manajemen” oleh J. Smith. Jakarta. Bumi Aksara

[18] Yukl, G. 2008. How leaders influence organizational effectiveness. Jurnal The Leadership Quarterly, volume 19: 708-722

[19] Wahab, Abdul, Jamalullail, 2014, Headmasters' Transformational Leadership and Their Relationship with Teacehrs' Job Staisfaction and Teacchers' Commitmen, International Education Studies, Published by Canadian Center of Science and Education; Vol. 7, No. 13

[20] Widodo, 2015. Kontruksi Kepemimpinan Pendidikan Non Formal Pada PKBM Yalatif Kabupaten Jombang. Disertasi S3 Pendidikan Luar Sekolah Universitas Negeri Malang

[21] Wirawan, 2013. Kepemimpinan (Teori, Psikologi, PerilakuOrganisasi, AplikasidanPenelitian).

RadjaGrafindoPersada, Depok 